\title{
What makes or breaks higher education community engagement in the South African rural school context: A multiple-partner perspective
}

\section{Eugene Gabriel Machimana, \\ Maximus Monaheng Sefotho and Liesel Ebersöhn \\ University of Pretoria, in South Africa}

\begin{abstract}
The purpose of this study is to inform global citizenship practice as a higher education (HE) agenda by comparing the retrospective experiences of a range of community engagement (CE) partners, and including often silent voices of non-researcher partners. HE-CE aims to contribute to social justice as it constructs and transfers new knowledge from the perspectives of a wide range of CE-partners. This qualitative secondary analysis study was framed theoretically by the transformative-emancipatory paradigm. Existing case data, generated on retrospective experiences of CE-partners in a long-term CE-partnership, were conveniently sampled to analyse and compare a range of CE-experiences (parents of student-clients $(n=$ 12: females 10, males 2$)$, teachers from the partner rural school $(n=18$ : females 12 , males 6), student-educational psychology clients ( $n=31$ : females 14, males 17), Academic ServiceLearning $(A S L)$ students $(n=20$ : females 17 , males 3$)$ and researchers $(n=12$ : females 11 , males 1).

Following thematic in-case and cross-case analysis, it emerged that all HE-CE partners experienced that socio-economic challenges (defined as rural-school adversities, include financial, geographic and social challenges) are addressed when an HE-CE partnership exists, but that particular operational challenges (communication barriers, time constraints, workload and unclear scope, inconsistent feedback as well as conflicting expectations) hamper HE-CE partnership. A significant insight from this study is that a range of CE-partners experience similar challenges when a university and rural school partner. All CE-partners experienced that HE-CE is challenged by the structural disparity between the rural context and operational miscommunication.
\end{abstract}

\section{Key words}

Barriers in community engagement, community engagement, global citizenship, higher education, partnership and partners, retrospective experiences, rural-school, social justice, transformative-emancipatory paradigm 


\section{Corresponding author:}

Eugene Gabriel Machimana, Department of Clinical Services, Faculty of Veterinary Science and Centre for the Study of Resilience, University of Pretoria, Private Bag x04, Onderstepoort, Pretoria, 0110, South Africa

Email: eugenemachimana@gmail.com

\section{Introduction}

In this article, like others (Trahair, 2013; Nestel et al., 2014), we argue that it is no longer enough to view society by means of the traditional role and voice of "the expert" without engaging non-researcher partners. The purpose of the article is to compare the retrospective experiences of higher education (HE)-rural school partners ${ }^{1}$ involved in community engagement (CE). HE aims to contribute to social justice through CE-partnerships as it constructs and transfers new knowledge and develops responsible global citizens (Jorgenson \& Shultz, 2012; Shultz, 2007; Webber \& Jones, 2011; Hayden, 2013). In this article, CE is manifested as global citizenship. The discourse on global citizenship is becoming the focal point in the HE curriculum agenda and practice (Shultz, 2007; Keating, Ortloff \& Philippou, 2009; Slamat, 2010; Osler, 2011).

The effort also to engage non-researcher partners in the current study enhanced community input in the global citizenship education agenda (Frey \& Whitehead, 2009; Trahair, 2013; Nestel et al., 2014). Similar to other researchers (Shultz, 2007; Frey \& Whitehead, 2009; Osler, 2011), we view global citizenship as understanding the common humanity and problems of injustice and inequality across national boundaries. CE-partnership has become an integral part of HE's mandate of teaching, learning and research (Bender, 2008; Gonzalez-Perez, 2010; Bowen, 2013). Engagement with non-researcher partners allows us to better understand the broader range of partnership relationships (Shields \& Evans, 2012), with specific reference to barriers in CE. Against this background, the transformativeemancipatory paradigm is used for reasoning, reflecting and exploring ways of fostering the emancipation of marginalised groups (Gall, Gall \& Borg, 2010; Lapum et al., 2012; Jacobs, 2014). The research question that this article answers is as follows: What are the common experiences of CE-partners of barriers in HE-CE-partnership?

\footnotetext{
${ }^{1}$ Parents of student-clients, teachers from the partner rural school, student-educational psychology clients, Academic Service-Learning (ASL) students and researchers
} 


\section{Transformative-emancipatory research and community engagement}

We argue in favour of the transformative-emancipatory paradigm, drawing from the theory of renowned education philosopher Paulo Freire, Pedagogy of the Oppressed (Freire, 1972; Freire, 1992; Irwin, 2012). Freire is a Brazilian, one of the greatest thinkers in education and the politics of liberation (McLaren \& Leonard, 1993). Well known for his literacy campaigns and seminar work relating to Pedagogy of the Oppressed, his thinking challenged the status quo of social, economic and political domination of the poor (Freire \& Macedo, 1987; McLaren \& Leonard, 1993). Like Freire, we argue that human beings are active beings, capable of reflection on their conditions and themselves (Freire, 1972; Freire, 1973; Freire, 1992; Freire, 1993). Through this critical reflection process, people are able to separate themselves from the world "in order to find their place in it and with it" (Freire, 1973, p. 105). The domination of the marginalised, either ideologically or physically, is the greatest tragedy of modern society. However, the marginalised are able to bring about transformation as they engage actively in reality with a critical and flexible spirit (Freire, 1972; Freire, 1973; Freire, 1992; Irwin, 2012).

Transformative-emancipatory strategies should be developed for sustainable human development and global citizenship (CCIC, 1996; Tilbury, 2011). Another dimension of the transformational paradigm relates to establishing relationship between donors and global issues that enhances the transformative perspective of development (CCIC, 1996). Donors who advocate this framework provide major funding for transformative research, which unlocks the potential for practical change in the community (Wagner \& Alexander, 2013). In the environment where the poor are marginalised, transformative researchers view their role as agents to advance social justice and democratic society (Levine, 2007; Mooij et al., 2011; Mertens, 2012; Wagner \& Alexander, 2013). In addition, transformationalist global citizens understand their responsibility, that of building relationships through embracing diversity and finding common humanity across national boundaries (Shultz, 2007; Frey \& Whitehead, 2009). It is imperative to pursue transformational solutions to local, national and global social and economic problems for the emancipation of marginalised and disempowered communities (David \& Clegg, 2008; Bruyere et al., 2013; Wagner \& Alexander, 2013).

The transformational lens used in this qualitative study informed the type of questions put, the way that data were collected and analysed, and includes a call for action or transformation (CCIC, 1996; Creswell, 2011). The theoretical lens provides an overall orienting lens for the study of HE-CE partnership with a marginalised rural school in the hope of increasing social justice (Creswell, 2011; Mertens, 2012). Consistent with the 
Transformative paradigm, we investigated the retrospective experiences of HE partners within their social context and focused on strengths that reside in the community (Mertens, 2012).

The assumption associated with this paradigm is that an individual partner should not be expected to implement change, but that change should, however, be a collaborative effort by community partners (CCIC, 1996). The goal of this study was to view transformation as a collaborative effort of all the partners who are involved (Freire, 1972; Freire, 1992). However, the power dynamics that exist between the researchers and the community and the cultural complexity of the community may hinder the process during interaction (Mertens, 2004; Mertens, 2005). By virtue of being associated with the university, we may be perceived to be holding a position of greater power, one which excludes the community from decisionmaking (Mertens, 2004; Mertens, 2005). Throughout our involvement ${ }^{2}$ with the community, we adopted the view of being an agent for advancing social justice working in collaboration with all the partners involved.

\section{Situating global citizenship in the context of rural schools in South Africa}

The current study of global citizenship took place in the context of the Flourishing Learning Youth (hereafter FLY) CE-partnership. FLY is an intervention that builds on a collaborative CE-partnership, and was established in 2005 between the University of Pretoria (Centre for the Study of Resilience) and a remote South African secondary school located in the Enhlanzeni District Municipality in Mpumalanga province (Ebersöhn, 2010a).

The FLY partner rural school referred to in this study is in Mpumalanga province in South Africa, a country whose total population is estimated at 54000000 (Statistics South Africa, 2014a). In 2011 Mpumalanga (38.3\%) was one of the four ${ }^{3}$ of nine provinces in South Africa where people were living below the upper-bound poverty line (Statistics South Africa, 2014b). Mpumalanga has 1867 ordinary public schools, thus counting amongst the top 5 provinces with the highest number of public schools (Department of Basic Education, 2014b). The statistics are based on data collected via the 2012 SNAP Survey for Ordinary Schools and Special Needs Education (SNE), which includes both independent and public ordinary schools and the 2012 Annual Survey for Early Childhood Development (ECD) (Department of Basic Education, 2014a). In 2012, the average national student-teacher ratio was 29.2:1, while Mpumalanga recorded 30.4:1 (Department of Basic Education, 2014a). The

\footnotetext{
${ }^{2}$ As a disclosed participant-observer

${ }^{3}$ Followed by Limpopo 50.9\%, Eastern Cape 47.5\% and KwaZulu-Natal 42\%
} 
disproportionately high number of students, namely 1057788 , in relation to teachers, who number 35000 in Mpumalanga, negatively affects the quality of education, particularly in rural schools (Department of Basic Education, 2014b).

In comparison with countries such as Brazil and China, South Africa is among the most unequal countries in the world (Nattrass \& Seekings 2001; Gardiner, 2008; The World Bank, 2012; Tregema \& Tsela, 2012; Oxfam, 2013; United Nations, 2013), which exacerbates the exposure of rural teachers, schools, students and their families to high-risk factors that threaten their well-being (Ebersöhn, 2014; De Villiers \& Van den Berg, 2012). The socio-politically unequal conditions in South Africa has its roots in 300 years of historical colonialism, which have been entrenched by 40 years of apartheid policies and 20 years of unequal conditions in the democratic era (Gelb, 2003; Angeles, 2005; Whitehead, Kriel \& Richter, 2005; Engelbrecht, Oswald \& Forlin, 2006; Seekings, 2007; Rohleder, Swartz, Carolissen, Bozalek \& Leibowitz, 2008; The World Bank, 2012), stripped the African majority in South Africa of their assets and distorted social institutions through racial discrimination (May, 1998).

Although apartheid policies were abolished in 1994 (May, 1998), high-risk rural communities still experience unequal education hurdles due to resource inequality, which is common in the South African education landscape (Leibowitz, 2010; Mapesela, Hlalele \& Alexander, 2012; The World Bank, 2012). Researchers concur that students in rural communities are still grappling with the legacy of social inequality and marginalisation, which renders them vulnerable to social risks such as a substandard education, unemployment, teenage pregnancy and drug abuse (Camino, 2000; Jenson \& Saint-Martin, 2003; Dass-Brailsford, 2005; Chipkin \& Ngqulunga, 2008). Some compounding socioeconomic risk factors affecting rural students include poverty, illiteracy, a high crime rate, violence, HIV and AIDS and orphanhood (Fasko \& Fasko, 1999; Ebersöhn \& Maree, 2006; Mathee et al., 2009; Cherrington, 2010; Mampane \& Bouwer, 2011; De Lange, Mitchell \& Bhana, 2012; Machimana, 2012; The World Bank, 2012).

\section{Global citizenship: Barriers in CE-partnerships}

Researchers (Maurrasse, 2001; Butcher et al. 2003) acknowledge that some barriers exist in CE-partnership, such as challenging partners, inadequate capacity of the community and development organisations, agenda and expectation conflict as well as a lack of funding (Moseley, 2007; Hart et al., 2009; Leibowitz, 2010). Mariage and Garmon (2003) claim that CE-partnership with underperforming and challenging schools demands too much effort to be 
able to meet the diverse and great needs. For this barrier to be overcome home and community should be connected as partners in the education of children (Mariage \& Garmon, 2003). The success of this kind of partnership cannot rest on the efforts of HE and challenged schools alone. Although various partners are instrumental in making a CE-partnership a success, they equally present challenges. For example, some CE-partnerships risk failure that may occur as a result of students' irresponsible behaviour (Lindenfeld, 2010).

Reitenaur et al. (2005) extrapolate that at student level, responsibility must be taken to ensure that the partners are not coerced or harmed in any way. The ethics clearance that students seek before participating in the research helps to guide their conduct. Presumably students adhere to the ethical guidelines when making decisions that affect community work. Like Bednarz (2008), we recommend that ethical protocols should be followed in order to protect all the partners involved. For example, timeframes should be negotiated from the outset and managed properly. It is crucial to review, evaluate and reflect on the partnership to ensure that ethical standards are upheld. In return the community partners may continue to lend their support long after the programme has been established.

Another factor confounding CE-partnership relates to the relationship between HE, the community and the development organisation. Moseley (2007) postulates that HE, the community and development organisation all approach $\mathrm{CE}$ with different motivations, expectations, constraints and challenges. The development organisation is often criticised for using staff without postgraduate qualifications to conduct research (Moseley, 2007). In return development organisations accuse academics of being very demanding, requiring vehicles and equipment to conduct research and so forth.

Furthermore, marginalised communities with limited resources may add to the challenges of a CE-partnership. The marginalised communities might struggle to make their voices heard in the partnership due to poor leadership (Fogel \& Cook, 2006; Vargas et al., 2012; Lindenfeld, 2010). If skills are not transferred to marginalised communities there is the potential of creating dependency, instead of capacitating them to be equal partners (Maurrasse, 2001; Beard \& Dasgupta, 2006). In a study conducted by Fogel and Cook (2006 p. 599), a community leader crudely described the unequal relationship between the community and university as being "like a prostitute, and we're the ones getting screwed". In spite of the above barriers and challenges, we argue that the challenges present a platform for collaborative CE-partnership that may solve real community problems (Mariage \& Garmon, 2003). As such, the study that we undertook seeks to hear the voices of community partners 
on barriers in CE-partnership, including the non-researchers, as equal partners in CEpartnership.

In some way, HE and communities share similar dynamics, because they both have diverse groups of individuals forming a community (Chipkin \& Ngqulunga, 2008, Andrews, 2011). Within both communities individuals bring social, political and economic dynamics to CE-partnership. Beere (2009) remarked that community groups have different priorities, goals, attitudes and strengths. Yet the resources of each partner are constrained by the reality of the demands (Minkler, 2005; Moseley, 2007; Leibowitz, 2010). Some of the demands that may have a constraining effect on the partnership relate to activities beyond the scope of the partnership. For example, academic researchers have the responsibility to teach, and also for learning at their own institutions (Colbeck \& Michael, 2006; O'Meara et al., 2011). Meanwhile, community constraints include being reluctant or unable to donate time and energy (Minkler, 2005; Moseley, 2007). The partners need to balance the requirements of the partnerships with their other responsibilities, such as academic demands.

Conflict is inevitable when HE and the community enter a CE-partnership with various agendas and expectations. Therefore, we support the notion of clarifying the agenda and expectations through a partnership agreement (McNall et al., 2009; Mahoney et al., 2010). Against this background of potential conflict, we suggest that the partners should undertake periodic review of the partnership agreement to prevent the relationship breaking down (Fogel \& Cook, 2006; McNall et al., 2009). It is worth noting that periodic review of the community partnership process may be a challenge for already overloaded academics. Nevertheless, Lindenfeld (2010) advises that CE should not be perceived as extra work for academics, but as work that requires them to work differently. Notwithstanding Lindenfeld's advice, we admit that some CE-partnerships fail to meet the expectations of the partners (McNall et al, 2009). Bringle and Hatcher (2002) observe that when the outcomes outweigh what is expected the partners will be satisfied with the partnership. We believe that the longitudinal comparative research that we conducted in the FLY partnership could shed light on how $\mathrm{CE}$ agenda and expectations hinder the relationship.

An additional challenge to HE-community partnership relates to funding. Lindenfeld (2010) accepts that academics who utilise the CE approach may face funding challenges. Maurrasse (2001) agrees that although some HE institutions, such as the University of Pennsylvania, may have large endowments for CE-partnership, it is nevertheless confronted with financial limitations. For example, the institution still has to raise funds from external funders. Some external funders impact on the longevity of CE-partnership, because of the 
requirements of the partnership (Maurrasse, 2001). We admit that effective change in communities requires long-term institutional support and stable funding (Benneworth \& Sanderson, 2009).

\section{Methodology}

\section{Research design: Secondary data analysis (comparative and qualitative)}

Secondary data analysis entails the use of existing data to investigate a phenomenon (Bassey, 1999; Jones \& Coffey, 2012; Irwin, 2013), which in this instance is an existing HE-rural school CE-partnership for informing global citizenship. The comparative secondary data analysis was conducted over two years. We observed (March 2013 to February 2015) the context as well as processes of data collection in the FLY intervention. By means of secondary analysis we aimed to produce in-depth descriptions and interpretations of a contemporary phenomenon ${ }^{4}$ for purposes of illumination and understanding of barriers in CE-partnership (Babbie \& Mouton, 2001; Creswell, 2003; Hays, 2004; Maree \& Pietersen, 2007; Lodico et al., 2010; De Vos et al., 2011). Arolker and Seale (2012) note that in secondary data analysis the researcher uses data that were collected by co-researchers. The secondary data are used for the purpose of developing additional or different scientific knowledge, interpretations and conclusions from those presented in the first results (Robson, 2002; Babbie, 2002; Bhatt, 2012). Some authors claim that a collaborative study approach is gaining prominence among educational researchers (Flyvbjerg, 2011; Grauer, 2012). However, the qualitative secondary data analysis approach is arguably underutilised (Irwin, 2013).

We used non-probability, convenience sampling 5 (Welman et al., 2005; Maree \& Pietersen, 2007; Henry, 2009; Babbie, 2013; McMillan \& Schumacher, 2014) to select qualitative secondary data from Participatory Reflection and Action (PRA) and qualitative survey studies. Existing case data, generated on retrospective experiences of CE-partners in a long-term CE-partnership, were conveniently sampled to analyse and compare a range of CEexperiences (parents of student-clients $(n=12$ : females 10, males 2), teachers from the partner rural school ( $n=18$ : females 12 , males 6$)$, student-educational psychology clients ( $n$ =31: females 14, males 17), Academic Service-Learning (ASL) students ( $n=20$ : females 17, males 3$)$ and researchers $(n=12$ : females 11, males 1$)$. The advantage of convenience

\footnotetext{
${ }^{4}$ FLY intervention

${ }^{5}$ Convenience sampling is also called availability sampling (Babbie, 2013; McMillan \& Schumacher, 2014; Neuman, 2014)
} 
sampling is that it allowed the authors to select qualitative secondary data that are available and accessible (Cohen et al., 2000; Welman et al., 2005; Henry, 2009; Babbie, 2013).

\section{Data analysis and interpretation}

We utilised inductive thematic analysis (Neuman, 1997; Eisenhart \& Jurow, 2011) to analyse and compare qualitative secondary data, namely verbatim transcriptions of PRA-directed group sessions, semi-structured interviews, audiovisual recordings, visual data in photographs and field notes (Ellingson, 2011; Harding, 2013; Babbie, 2013). The purpose of inductive thematic analysis is to compare trends across partner cohorts (Rivas, 2012). The main objective of inductive thematic analysis is three-fold, namely examining commonality, examining differences and examining relationships (Harding, 2013).

Our interest in this article was to compare the partners' retrospective experiences of a long-term HE-rural school partnership to inform the HE-CE agenda in order to establish commonality, differences and relationships in the data (Charmaz, 2011; Harding, 2013). The common themes that emerged were analysed and compared by means of inductive reasoning throughout the study (Cohen \& Manion, 1994; Neuman, 1997; Cohen et al., 2000; Adler \& Clark, 2008).

The current study had two phases of data analysis and comparison, namely in-case analysis and cross-case analysis. The authors first analysed the qualitative data of the partner cohorts separately to establish the emerging themes. After completing the first phase, namely inductive thematic analysis, we compared the results of the partners to examine commonality, differences and relationships (Harding, 2013). After establishing the results, we conducted further literature review to establish the relationship between the results and existing knowledge (Harding, 2013).

\section{Ethical considerations}

We argue that the underlying principles of research should be "mutual trust, acceptance, cooperation, promises and well-accepted conventions and expectations" (De Vos et al., 2011, p. 113) between the FLY partners involved in this research project. On this basis, ethical behaviour is important in PRA and qualitative survey research, in particular because it involves human participants (Welman et al., 2005). Throughout the research process, we espoused the principles of ethical research processes (Welman et al., 2005). We argue that it is crucial to abide by a professional code of ethics in social research in order to protect the research, the participants and co-researchers (Babbie \& Mouton, 2001). 
Throughout this study, we adhered to the ethical guidelines stipulated by the Ethics Committee of the University of Pretoria. Notwithstanding the effect of our presence on-site, we abided by the ethical guidelines (Babbie \& Mouton, 2001), such as obtaining institutional approval for research and access to secondary data (copyright) as we wanted to maintain a good reputation with both the university and the community (Barbour, 2008; Department of Education, 2009). Furthermore, we only used the data that was collected from the participants who gave voluntary informed consent (De Vos et al., 2011) to the co-researchers prior to PRA and qualitative survey studies being conducted (Lawrence \& Gabriella, 2004; Bickman \& Rog, 2009).

We strictly followed the ethical guidelines prior to collecting qualitative secondary data in order to protect the research participants, the integrity of the co-researchers and the long-term relationship that had been established by the principal investigator (Jones \& Coffey, 2012; Jackson et al., 2013). For underpinning the quality criteria of this study, trustworthiness is determined by four indicators, which are credibility, dependability, transferability and confirmability (Kumar, 2011; Lincoln, 2011).

\section{Limitations of the study}

This study presents empirical evidence of contribution to the knowledge base on global citizenship as an HE agenda, although the findings should be read against its limitations. Firstly, secondary data are often collected by other researchers (Neuman, 1997; Cohen et al., 2000; Lodico et al., 2010) and may not be appropriate for a different research purpose (Babbie \& Mouton, 2001; Robson, 2002). Typically this occurs when the primary research questions do not relate to the study of a secondary analyst. Secondly, the findings are limited to the experiences of cohort partners, because it is a retrospective study (Cohen et al., 2000; Arolker \& Seale, 2012). Thirdly, the research design (qualitative secondary data analysis) had limitations of generalisability (Babbie \& Mouton, 2001; Creswell, 2003), although the results of this study are transferable to similar settings (namely rural settings), because it provided rich data (Bazeley, 2013). Finally, we used inductive thematic analysis, which is inherently limiting as data is fragmented during the coding process (Bryman, 2001). In addition, this process interferes with the flow of the narrative of the CE-partners. 


\section{Results:}

Multiple-partner perspectives on barriers in rural school contexts that require or hamper a HE-CE partnership

In this section, we report on two main themes that emerged from the qualitative secondary data, namely: socio-economic challenges in HE-CE partnership and operational challenges affecting HE-CE partnership. Each theme is supported by subthemes as elaborated below. Socio-economic challenges that are defined as rural-school adversities are addressed when an HE-CE partnership exists include financial, geographic and social challenges. Operational challenges related to partners' shared views on operational factors that hampered a HE-CE partnership, including communication barriers, time constraints, workload and unclear scope, inconsistent feedback as well as conflicting expectations.

\section{Socio-economic challenges in HE-CE partnership}

Financial constraints were experienced as a challenge which requires intervention, such as HE-CE partnership. A parent remarked on how a lack of finances affected the future education of the current students:

They are thinking that they do not have enough money to get their children to universities (Interpreter for Unidentified Female Speaker, Lines 3-4). A researcher confirmed that the financial implication thereof is a challenge for remote schools (Participant 3, Questionnaire, Line 44). A teacher reported that the same parents were hoping to gain financially by participating in the FLY intervention: Another challenge we got is that, you know, [in] the areas where we are teaching, there is a lot of unemployment. So when the project started they wanted to earn as soon, you know, when it was started they were expecting to earn money, [an] income, at the end of the month, because there are challenges at home (Group 1, Participant 1, Lines 80-84).

However, a representative of the ASL students stated that participating in CE with a resource-constrained rural school gave them invaluable experience and enriched their studies: Students gained experience in community engagement as well as understanding [of] the specific challenges of working in a setting with limited financial resources and being relatively geographically isolated (Participant 8, Online, Lines 83-85).

Geographic isolation of rural schools served as a common barrier needing support, which an HE-CE alliance provides. The physical distance between the university and the rural school as well as rurality are risk factors in HE-CE partnership. A teacher described the frustration that: The programme is actually based in our sites, where we are stationed. The 
university is high up there; as indicated, the distance is a challenge. They are $300 \mathrm{~km}$ [pointing up] away and we are here [pointing down] (Group 3, Participant 12, Lines 163165). A student confirmed that they are also disappointed with the number of days allocated per visit: They came here for two days to visit us; it would be better to us if they stayed for the week with us... (Group 3, Participant 14, Lines 87-88).

ASL students and researchers affirmed that the distance between the university and the rural school hampered CE-partnership. They explained the hindrance as follows: The distance makes more intensive support and intervention difficult (Participant 5, Online, Line 25). Distance - to establish frequent visits and adequate communication between partners (Participant 8, Questionnaire, Lines 56).

Parents shared how social challenges, such as drugs, teenage pregnancy and childheaded households in a rural school community could be positively affected in the presence of an HE-CE partnership. The partners are not only aware of this situation, but they are intervening with the aim of building a better society. Verbatim quotations, as narrated by the participants, substantiate this analysis:

You are helping the learners stay away from dangerous things like drugs (Interpreter for Unidentified Female Speaker, Lines 1-2).

It will give us skills of how to intervene [in] and guide child-headed homes (Group 4, Participant 17, Lines 206-207).

It is because difference [different] people, different young of today, they are involved in different things, we all know that, alcohol and all those stuffs (Group 1, Participant 1, Lines 106-108).

Risk factors within the learners' environment, e.g. drugs, negative influences, illness, etc. (Participant 3, Telephonic, Line 22).

\section{Operational challenges affecting HE-CE partnership}

Communication challenges were experienced across the spectrum of partners as an impediment in the functioning of a culturally diverse group in an HE-CE partnership. Some non-researcher partners struggled to speak English. Similarly, some team members from the university did not speak or understand the rural-community's languages. However, the participants also acknowledged that there is a general improvement in the use of English as medium of instruction at the school, partly as a result of the FLY intervention. This is evident in the following verbatim extracts from the participants' narrations: 
A student seems to have confirmed this observation by stating that: They helped us; improved communication skills, [for] example, how to communicate with someone from a different culture (Group 1, Participant 3, Lines 23-24).

Teachers went further to highlight a lack of communication as a factor that hampers CE-partnership: And also we have spoken about the lack of communication [he paused for a moment and smiled] which is coupled with the lack of cooperation within the school community. There is a challenge with communication in our schools and we are aware of that (Group 3, Participant 12, Lines 181-183).

ASL students and researchers vented their frustration with language barriers. Their frustrating experiences are captured in the following verbatim quotations: Language barriers were a little frustrating (Participant 13, Online, Line 248). Another ASL student voiced this: Language barrier: I am black, but a foreigner, so I do not speak any of the South African languages. I felt bad when the learners spoke something as we were interacting and I was not able to understand what they were saying (Participant 15, Face-to-face, Lines 358-360).

A researcher experienced difficulties with providing therapy as a result of language differences: This was difficult for me to be honest ... emmmm ... but ... emmm ... I think it was very difficult for me to do therapy with the children because of the language barrier and it was such a learning curve because in the end I could see why I need to go out there. But the language barrier was definitely a limitation (Participant 1, Telephonic, Lines 1-4). Another researcher echoed the sentiments: I found communication with learners [language barrier] challenging (Participant 8, Questionnaire, Line 86).

Although all HE-CE partners reported time constraints as a factor that may hamper the partnership, rural students seem to want more time to be invested in the relationship. The partners understood that schedule for visiting a rural school means a limited period as the partners have other responsibilities outside this partnership. It appears that work responsibilities of the participants (outside this partnership) create strain if they are not managed properly. A parent made a passionate plea for students to maximise the opportunity they are offered within the limited period of time:

They hope that their children do not waste their time so that they can pay back when they are done (Interpreter for Unidentified Female Speaker, Lines 6-7). In contrast, the students are aware of the limitations of time, but they want more from this partnership:

Okay, what we did not like is they did not spend enough time with us. They did not give us enough time ... the visiting period. Maybe they were supposed to give us ... uhmm ... 
a month or more than a month so we have enough information of what they were telling us about (Group 2, Participant 7, Lines 53-55).

The participants who are in full-time employment indicated that the workload restricted the amount of time they could invest in CE-partnership. The following verbatim extracts provide evidence of this claim: So most of the time we do not have time. We are unable to help the community, so it is a big challenge when it comes to that one (Group 1, Participant 1, Lines $56-57)$.

Time constraints: I felt that I did not have enough time to do everything that I want to do with the learners (Participant 15, Face-to-face, Lines 361-362).

Therefore, when partnering with teachers, their work responsibilities and related time constraints should be respected and managed proactively by clarifying the partners' demands on the time and outputs required (Participant 6, Questionnaire, Lines 69-71).

Most of the partners who participated in this study reported that their workload and lack of clarity on the scope of the partnership hampered the partnership. The degree of workload strain differed among individual partners depending on several factors. For instance, international research partners were restricted in terms of consistent on-site involvement. A representative of the teachers also lamented their workload:

And another one we said [is] workload. As educators, you know, we are overloaded (Group 1, Participant 1, Line 54). An ASL student stated her understanding of the scope of the intervention as follows:

But, ja, my understanding of it was we go in twice during the year. Once [to] do the assessment, the second time [to] do the feedback sessions, so to speak. And that was as far as I was concerned the scope of the project, or our involvement in the project (Participant 16, Online, Lines 159-162). An overseas-based FLY associate reflected:

Other difficulties are more related to the workload experienced by this international colleague, and I am sure others are similarly limited by the time they can commit to this endeavour. My involvement in the investigation of second language teaching in the two remote schools, and co-supervision of a Masters student, has not been as consistent as I would like it to have been, but that is not a reflection on the FLY partnership (Participant 4, Questionnaire, Lines 26-30).

All partners identified inconsistent feedback sessions as an impeding factor that negatively impacts an HE-CE partnership. Although feedback sessions did occur, these were not as regular as they would have expected. The non-researcher partners were expecting regular feedback from the researcher partners and vice versa. Parents and teachers struggled 
to offer appropriate follow-up interventions in the absence of progress reports from the ASL students and researchers. Researchers indicated that feedback reports from rural school partners could assist in assessing the strengths and weaknesses of the partnership. The following verbatim extracts from PRA-directed group sessions and qualitative surveys confirm this analysis:

During a PRA-directed group session a teacher reported that: Point number three: The university must give us feedback after they visited the school, so that we can know [pause] know how the process is working (Group 2, Participant 5, Lines 13-14). Parents supported the idea: They will be very grateful if you can come again because they want you to come back (Interpreter for Unidentified Female Speaker, Lines 7-8). Students wanted not only feedback reports, but also to see the video recordings that had been made during sessions: Okay, the feedback about the visits, [for] example [the] videos they took. They were supposed to come back with the videos and show us what they were doing with the videos and then we, let us know more about ... uhmm ... I can say, if maybe they bring the videos for us to see, maybe what they do with the videos when they present them to the university, yes (Group 2, Participant 7, Lines 60-63).

ASL students emphasised that there was a need for: Continued reassessment of what has been done and reflection and feedback from the school and the students there (the children on what they would want/need) (Participant 5, Online, Lines 38-39). They expected feedback at least from: Constant feedback from teachers, students, management (i.e. needs assessment) (Participant 6, Online, Line 40). This could help the partnership: Feedback from learners is able to assist in identifying the strengths and weaknesses of the partnership (Participant 9, Questionnaire, Lines 133-134).

All HE-CE partners expressed that conflicting expectations (high expectations, unqualified benefits and failure to deliver on expectations) were detrimental to a partnership. Some partners expected financial benefits from participating in an HE-CE partnership. The following verbatim quotations illustrate the partners' diverse expectations of CE-partnership: If benefits are not clarified, you know, people will expect that the Messiah has come [giggle]. The university has landed, every problem is gonna [going to] be solved (Group 3, Participant 12, Lines 208-210).

The lack of delivery on expectations is the biggest barrier to the partnership. Is on both sides actually, because I think the university has expectations of us (Group 3, Participant 12, Lines 161-162). As we expect a lot from the university, as indicated, high expectations (Group 3, Participant 12, Line 157). 
Partners expect too much (Participant 7, Online, Line 34). I remember doing soulsearching, whether we were just opening up expectations, hopes of learners and their families, and then leaving them (Participant 17, Telephonic, Lines 457-459).

Teacher partners also said that they expected some form of financial gain from the partnership. It is therefore important to clarify and manage all partners' expectations from the onset of the partnership (Participant 6, Questionnaire, Lines 48-50).

\section{Discussion}

Across the board in HE-partnerships in a highly unequal society, anticipate expectations related to financial constraints, multilingualism, and social challenges. Common challenges experienced by all partners were that of financial constraints, communication and social challenges - as indicated in Table 1:1. By implication, in similar contexts of HE-partnerships, it is plausible to anticipate similar concerns related to financial constraints and accompanying expectations, barriers associated with multilingualism, as well as social challenges that necessitate partnerships with universities.

Table 1:1: Common experiences between all the FLY partners

\begin{tabular}{|c|c|}
\hline Participants & Financial constraints and expectations \\
\hline Parent & $\begin{array}{l}\text { They are thinking that they do not have enough money... (Interpreter for Unidentified Female } \\
\text { Speaker, Lines 3-4). }\end{array}$ \\
\hline Teacher & $\begin{array}{l}\text {...they were expecting to earn money, [an] income, at the end of the month, because there are } \\
\text { challenges at home (Group 1, Participant } 1 \text {, Lines } 80-84 \text { ). }\end{array}$ \\
\hline ASL student & $\begin{array}{l}\text {...understanding }[\mathrm{of}] \text { the specific challenges of working in a setting with limited financial } \\
\text { resources... (Participant } 8 \text {, Online, Lines } 83-85 \text { ). }\end{array}$ \\
\hline Participants & Multilingualism challenges \\
\hline Student & $\begin{array}{l}\text { They helped us; improved communication skills, [for] example, how to communicate with } \\
\text { someone from a different culture (Group 1, Participant 3, Lines 23-24). }\end{array}$ \\
\hline Teacher & $\begin{array}{l}\text {...learners experiencing challenges in terms of language of teaching and learning which } \\
\text { hinders them to perform eh well in their studies (Group 13, Participant 7, Lines 105-106). }\end{array}$ \\
\hline ASL student & $\begin{array}{l}\text { Language barrier: I am black, but a foreigner, so I do not speak any of the South African } \\
\text { languages (Participant 15, Face-to-face, Lines 358-360). }\end{array}$ \\
\hline Researcher & But the language barrier was definitely a limitation (Participant 1, Telephonic, Lines 1-4). \\
\hline Participants & Social challenges and the need for university partnerships \\
\hline Student & $\begin{array}{l}\text {...different young [people] of today, they are involved in different things, we all know that, } \\
\text { alcohol and all those stuffs (Group 1, Participant 1, Lines 106-108). }\end{array}$ \\
\hline Teacher & $\begin{array}{l}\text { It will give us skills of how to intervene [in] and guide child-headed homes (Group 4, } \\
\text { Participant 17, Lines 206-207). }\end{array}$ \\
\hline ASL students & $\begin{array}{l}\text { Risk factors within the learners' environment, e.g. drugs, negative influences, illness, etc. } \\
\text { (Participant 3, Telephonic, Line 22). }\end{array}$ \\
\hline
\end{tabular}

Others (Cheong, 2006; Butcher et al., 2011) in the field of global citizenship have found that community partners have limited finances to contribute in HE-CE partnership. Butcher et al. (2011) emphasise that community partners must be realistic about their contribution of 
resources, including people, time and the finances required to make the intervention a success. Participants reported that financial constraints affected the partnership as well as them personally.

The expectation for economic relief due to participation in the CE-partnership is consistent with the finding of Ashcroft and Rayner (2011). They content that, in Sub-Saharan universities, the purpose of research and $\mathrm{CE}$ should be to generate knowledge aimed at addressing social and economic challenges. The quandary of financial constraints is exacerbated by findings that confirm that, in South Africa; financial support for CE is limited despite the emphasis on the necessity that HE engages with communities (Erasmus, 2014). In the same vein, Ebersöhn et al. (2010) state that financial and physical resources continue to limit opportunities for rural students and that one negative outcome of such resource constraints is that of limited services by Educational Psychologists in South Africa at large, and intensely so in rural communities. Moreover, participants were concerned that feedback sessions were inconsistent. The potential challenges to CE-partnership were compounded by the conflicting expectations of the partners involved. Similarly, Moseley (2007) emphasised the importance of sharing findings and giving feedback in CE-partnership. Erasmus (2014) highlighted that there could be a discrepancy between practice and partners' expectations in CE.

In a culturally diverse environment language can be a barrier in CE-partnership. Cheong's (2006) study showed that people resisting engagement in a common, shared language can hinder social relationships. We found that all partner-groups experienced the presence of multiple languages as a challenge. Yet this experience did not take the form of resistance against participation. The outcome of this study is similar to that in existing literature, as recorded by Chipkin and Ngqulunga (2008), namely that a language barrier is a practical challenge in South Africa, given that it has 11 official languages. Other studies also confirm that language can cause a communication barrier in a multi-cultural environment (Loots, 2011; Venter, 2013).

Participants across the five datasets commented on the presence of social challenges that necessitate a HECE-partnership. These results are consistent with those of Cheong (2006), who found that crime and drugs breed social mistrust and fear in society. Literature within the context of HE-CE mentions the following as examples of social challenges that may hinder partnership: drugs, crime and teenage pregnancy (Cherrington, 2010; Osman \& Petersen, 2010; Ashcroft \& Rayner, 2011; Albertyn \& Erasmus, 2014; Pitso, 2014). Others have found that where students grow up in poverty negative outcomes occur and can lead to 
intergenerational transfer of poverty (Albertyn \& Erasmus, 2014; Pitso, 2014). Negative outcomes include: learning difficulties, dropping out of school, abusing drugs, committing crime and teenage pregnancy (Cherrington, 2010; Ashcroft \& Rayner, 2011; Machimana, 2012).

We argue, through the lens of a transformative emancipatory paradigm, that such expectations can be galvanised as opportunities for change. Knowing that, of all the possible risks to a partnership in a global south setting, these challenges are most often those commonly shared by stakeholders is significant when designing, negotiating, as well as monitoring and evaluating a HE-partnership. During development stages it would imply intentionally creating a space for dialogue where these challenges are tabled as topics for clarification. In a monitoring and evaluation framework these challenges need to be deliberately screened to determine their impact on the progress of outcomes.

With regards to transformation these quandaries also promise opportunities to move beyond dialogue and accountability of a partnership. The opportunity of sharing diversity spaces affords opportunities for researchers, students and community-members alike to become adept in functioning despite economic differences, social dissimilarities and multilingualism. Ideally such shared spaces of dialogue and developing socio-cultural competence given inequality would also incite action across the spectrum of partnershipstakeholders to address structural disparity at the heart of these anticipated barriers.

Depending on the HE-partner, expect challenges regarding the place of the HEintervention community, time and workload constraints, and feedback needs. According to Beere (2009) geographical location may influence the decision of HE when choosing a community partner. In Caputo's view (2005), small towns and rural communities may have limited opportunities for CE. Similarly, we found that participants are concerned about the limitations imposed by the distance between the rural school and the university. Many participants viewed the limited number of days allocated for contact engagement as a risk factor associated with distance. Closely linked to this issue is time as a factor that hinders the partnership.

We argue that time constraints may hinder HE-CE partnership. Similar findings were recorded by other researchers, who indicated that the community may be reluctant or unable to donate time and energy to the partnership (Minkler, 2005; Butcher et al., 2011; Webber \& Jones, 2011; Markham, 2013). As revealed by the results of the current study, Bednarz et al. (2008) focus on the quality of time and effort it takes for community partners to have an authentic and lasting impact. The participants who are working are restricted by their 
workloads, yet they are aware that a once-off engagement may have a negative impact on the community (Bednarz et al., 2008).

In this study, the degree of workload was also dependant on whether the participant was based at the rural school, university or overseas. Although Webber and Jones (2011) report that some academics are hesitant to engage with communities because of a lack of support and time, also lamenting a heavy workload, the participants added that their inconsistent on-site involvement was not a reflection on the FLY intervention. Likewise, the current study affirms that progress has been made in CE. However, there is still a need for clarity of scope, both in theory and practice (Webber \& Jones, 2011). Fogel and Cook (2006) argue that community partners should be in a position to determine the phases of the relationship and whether expectations are being achieved based on the scope of the work.

Furthermore, participants in this study indicated that regular feedback sessions could assist in assessing the strengths and weaknesses of the partnership. This should be a two-way process, whereby the researcher partners provide feedback to non-researcher partners and vice versa. On the same note, Strier (2011) conducted qualitative interviews and found that positively showing respect for the community and providing feedback are crucial parts of capacity-building. In addition, conflicting interests, bureaucracy and poor planning are potential barriers to CE-partnership (Strier, 2011). The findings were also consistent with the current study as participants reported that conflicting expectations could emanate from any of the partners involved in the FLY intervention.

\section{Conclusion}

This study is unique in that not much research has included experiences of a wide range of partners who are involved in HE-CE partnerships. Contrary to expositions in existing literature, participants did not prominently describe the community in the context of CEpartnership in social terms. All CE-partners experienced that HE-CE is challenged by the structural disparity between the rural context and operational miscommunication. We argue that leveraging knowledge of shared challenges (anticipations due to financial constraints, social problems and multiligualism) could be used intentionally to create HE-partnership spaces that are transformative. If unaddressed over time such typical challenges could stymie a HE-partnership. At the very least dialogue on expectations could clarify partnerexpectations. Integrating predictable challenges deliberatly into a partnership plan could potentially promote socio-cultural adeptness amongst partners as they reflexively engage 
with one another - cognisant of shared concerns in the partnership. And at most, social responsibility and social justice may be manifested in the eventuality that HE-partners act or advocate in protest against structural disparities which drive joint concerns.

\section{Acknowledgements}

We acknowledge the financial support for this study, which was provided by the National Research Foundation (NRF) for the Flourishing Learning Youth (FLY) intervention (Grant number: 82620 CEC12091412827). We acknowledge the parents, teachers, student-clients, ASL students and researchers who participated in this study. We acknowledge in particular the co-researchers from the Centre for the Study of Resilience, University of Pretoria, Lidalize Grobler, Marli Edwards, Seago Seobi, Ina-Mari du Toit and Alicia Adams, who cogenerated data. 


\section{References}

Adler, E. S., \& Clark, R. (2008). How It's Done: An Invitation to Social Research ( $3^{\text {rd }}$ ed.). Wadsworth: Thomson.

Albertyn, R., \& Erasmus, M. (2014). An introductory perspective on the knowledge enablement landscape: Potential for higher education-third sector engagement. In R. Albertyn, \& M. Erasmus (Eds.), Knowledge as Enablement: Engagement between higher education and the third sector in South Africa (pp. 21-37). Bloemfontein: Sun Press.

Andrews, R. (2011). Religious Communities, Immigration, and Social Cohesion in Rural Areas: Evidence from England. Rural Sociology, 76(4), 535-561.

Angeles, L. (2005). Income Inequality and Colonialism. University of Lausanne, 1-30.

Arolker, M., \& Seale, C. (2012). Glossary. In C. Seale (Ed.), Researching Society and Culture ( $3^{\text {rd }}$ ed., pp. 555-604). Thousand Oaks, CA: Sage.

Ashcroft, K., \& Rayner, P. (2011). Higher Education in Development: Lessons from SubSaharan Africa. New York: Information Age Publishing.

Babbie, E., \& Mouton, J. (2001). The practice of social research. South African edition. Cape Town: Oxford University Press.

Babbie, E., \& Benaquisto, L. (2002). Fundamentals of research ( $2^{\text {nd }}$ ed.). Canada: Thomson.

Babbie, E. (2013). The practice of social research (13 ${ }^{\text {th }}$ ed.). Canada: Wadsworth.

Barbour, R. (2008). Introducing qualitative research: A Student Guide to the Craft of Doing Qualitative Research. Los Angeles: Sage.

Bassey, M. (1999). Case study research in educational settings. Buckingham: Open University Press.

Bazeley, P. (2013). Qualitative Data Analysis: Practical Strategies. Los Angeles: Sage.

Beard, V. A., \& Dasgupta, A. (2006). Collective Action and Community-driven Development in Rural and Urban Indonesia. Urban Studies, 43(9), 1451-1468. 
Bednarz, S. W., Chalkley, B., Fletcher, S., Hay, I., Le Heron, E. L., Mohan, A., \& Trafford, J. (2008). Community Engagement for Students Learning in Geography. Journal of Geography in Higher Education, 32(1), 87-100.

Beere, C. (2009). Understanding and Enhancing the Opportunities of Community-Campus Partnerships. In L. R. Sandmann, C. H. Thornton, \& A, J. Jaeger, (Eds.), Institutionalizing Community Engagement in Higher Education: The First Wave of Carnegie Classified Institutions (pp. 55-63). San Francisco: Wiley Periodicals.

Bender, G. (2008). Exploring conceptual models for community engagement at higher education institutions in South Africa. Perspectives in Education, 26(1), 81-95.

Benneworth, P., \& Sanderson, A. (2009). The Regional Engagement of Universities: Building Capacity in a Sparse Innovation Environment. Higher Education Management and Policy, 21(1), 131-148.

Bhatt, C. (2012). Doing a dissertation. In C. Seale (Ed.), Researching Society and Culture (3 ${ }^{\text {rd }}$ ed., pp. 153-178). Thousand Oaks, CA: Sage.

Bickman, L., \& Rog, D. J. (2009). Applied Research Design: A Practical Approach. In L. Bickman, \& D. J. Rog (Eds.), The SAGE Handbook of Applied Social Research Methods ( $2^{\text {nd }}$ ed., pp.3-43). Thousand Oaks, CA: Sage.

Bowen, G. A. (2013). A Civic Engagement Agenda for Caribbean Higher Education. Journal of Community Engagement and Higher Education, 5(1), 74-81.

Bringle, R. G., \& Hatcher, J. A. (2002). Campus-Community Partnerships: The Terms of Engagement. Journal of Social Issues, 58(3), 503-516.

Bruyere, B. L., Roybal, M., \& Thomas, R. (2013). Dispositions of Higher Education Faculty Toward K-12 Community Outreach. Journal of Community Engagement and Higher Education, 5(1), 57-69.

Bryman, A. (2001). Social Research Methods. Oxford: Oxford University Press.

Butcher, J., Howard, P., Labone, E., Bailey, M., Smith, S. G., McFadden, M., ... Martinez, K. (2003). Teacher Education, Community Service Learning and Student Efficacy for Community Engagement. Asia-Pacific Journal of Teacher Education, 31(2), 109-124. 
Camino, L. A. (2000). Youth-Adult Partnerships: Entering New Territory in Community Work and Research. Applied Development Science, 4(1), 11-20.

Canadian Council for International Cooperation. (1996). Global citizenship: A new way forward. Retrieved from http://www.ccic.ca/_files/en/what_we_do/002_public_a new way forward.pdf

Caputo, D. (2005). A Campus View: Civic Engagement and the Higher Education Community. National Civic Review, 3-8.

Charmaz, K. (2011). Grounded theory methods in social justice research. In N. K. Denzin, \& Y. S. Lincoln (Eds.), The SAGE Handbook of Qualitative Research (4 ${ }^{\text {th }}$ ed., pp.359380). Thousand Oaks, CA: Sage.

Cheong, P. H. (2006). Communication Context, Social Cohesion and Social Capital Building among Hispanic Immigrant Families. Community, Work and Family, 9(3), 367-387.

Cherrington, A. M. (2010), Learners experiences of school violence in a rural school, MEd dissertation, University of Pretoria, Pretoria, viewed 2014/03/07 < http://upetd.up.ac.za/ thesis/available/etd-06132011-144001/ >.

Chipkin, I., \& Ngqulunga, B. (2008). Friends and Family: Social Cohesion in South Africa. Journal of South African Studies, 34(1), 61-76.

Chovane, D. M., Gordon, N., Underwood, M., Butt, S., \& Diaz, R. S. (2015). Solidarity Movements and Decolonization: Exploring a Pedagogical Process. In A. A. Abdi, L. Shultz, \& T. Pillay (Eds.), Decolonizing Global Citizenship Education (pp. 157-172). Rotter Dam: Sense Publishers.

Cohen, L., \& Manion, L. (1994). Research methods in Education (4 ${ }^{\text {th }}$ ed.). London: Routledge.

Cohen, L., Manion, L., \& Morrison, K. (2000). Research Methods in Education (5 ${ }^{\text {th }}$ ed.). London: Routledge Falmer.

Colbeck, C. L., \& Michael, P. W. (2006). The Public Scholarship: Reintegrating Boyer's Four Domains. New Directions for Institutional Research, 129, 7-19. 
Cossa, J. (2013). Power Dynamics in International Negotiations towards Equitable Policies, Partnerships, and Practices: Why it Matters for Africa, the Developing World, and their Higher Education Systems. African and Asian Studies, 12, 100-117.

Creswell, J. W. (2003). Research Design: Qualitative, Quantitative, and Mixed Methods Approaches $\left(5^{\text {th }}\right.$ ed). Thousand Oaks, CA: Sage.

Creswell, J. W. (2011). Controversies in mixed methods research. In N. K. Denzin, \& Y. S. Lincoln (Eds.), The SAGE Handbook of Qualitative Research (4 ${ }^{\text {th }}$ ed., pp. 269-283). Thousand Oaks, CA: Sage.

Dass-Brailsford, P. (2005). Exploring resiliency: Academic achievement among disadvantaged black youth in South Africa. South African Journal of Psychology, 35(3), 574-591.

David, M., \& Clegg, S. (2008). Power, pedagogy and personalization in global higher education: the occlusion of second-wave feminism? Discourse: Studies in the Cultural Politics of Education, 29(4), 483-498.

De Lange, N., Mitchell, C., \& Bhana, D. (2012).Voices of women teachers about gender inequalities and gender-based violence in rural South Africa. Gender and Education. 24(5), 499-514.

Department of Basic Education. (2014b). 2014 School Realities. Retrieved from http://www.education.gov.za/LinkClick.aspx?fileticket=UdGRjcHLNik\%3d\&tabid=4 $\underline{62 \& \mathrm{mid}=1327}$

De Villiers, M., \& Van den Berg, H. (2012). The implication and evaluation of resiliency programme for children. South African Journal of Psychology, 42(1), 93-102.

De Vos, A. S., Strydom, H., Fouché, C. B., \& Delport, C. S. L., (2011). Research at Grass Roots: For the social sciences and human services professions ( $4^{\text {th }}$ ed.). Pretoria: Van Schaik.

Ebersöhn, L. (2010a). Resilience and Career Counselling: Describing the utility of Quadrant Mapping. Journal of Psychology in Africa, 20(3), 386-393.

Ebersöhn, L. (2014). Teacher resilience: theorizing resilience and poverty. Teachers and Teaching: Theory and Practice, 1-27. 
Ebersöhn, L., \& Maree, J. G. (2006). Demonstrating resilience in an HIV\&AIDS context: An emotional intelligence perspective. Gifted Education International, 22(1), 14-30.

Ebersöhn, L., Bender, C. J. G., \& Carvalho-Malekane, W. (2010). Informing educational psychology training with students' community engagement experiences. Perspectives in Education, 28(3), 87-98.

Eisenhart, M., \& Jurow, A. S. (2011). Teaching qualitative research. In N. K. Denzin, \& Y. S. Lincoln (Eds.), The SAGE Handbook of Qualitative Research (4 ${ }^{\text {th }}$ ed., pp.699-714). Thousand Oaks, CA: Sage.

Ellingson, L. L. (2011). Analysis and representation across the continuum. In N. K. Denzin, \& Y. S. Lincoln (Eds.), The SAGE Handbook of Qualitative Research (4 ${ }^{\text {th }}$ ed., pp. 595610). Thousand Oaks, CA: Sage.

Engelbrecht, P., Oswald, M., \& Forlin, C. (2006). Promoting the implementation of inclusive education in primary schools in South Africa. British Journal of Special Education, 33, 121-129.

Erasmus, M. (2014). The Political Unconscious of higher education community engagement in South Africa. In R. Albertyn, \& M. Erasmus (Eds.), Knowledge as Enablement: Engagement between higher education and the third sector in South Africa (pp. 100118). Bloemfontein: Sun Press.

Fasko, S. N., \& Fasko, D. (1999). A system approach to self-efficacy and achievement in rural schools. Education, 119(2), 292-300.

Flyvbjerg, B. (2011). Case Study. In N. K. Denzin, \& Y. S. Lincoln (Eds.), The SAGE Handbook of Qualitative Research (4 ${ }^{\text {th }}$ ed., pp. 301-316). Thousand Oaks, CA: Sage.

Fogel, S. J., \& Cook, J. R. (2006). Considerations on the scholarship of engagement as an area of specialization for faculty. Journal of Social Work Education, 42(3), 595-606.

Frabutt, J. M. (2010). Supporting Community Safety through University-Community Partnerships: Exploring Models of Engagement. Journal of Community Engagement, $1(2), 1-13$.

Freire, P., \& Macedo, D. (1987). Literacy: Reading the Word and the World. London: Routledge and Kegan Paul. 
Freire, P. (1972). Pedagogy of the Oppressed. New York: Penguin Boos.

Freire, P. (1973). Education for Critical Consciousness. New York: The Seabury Press.

Freire, P. (1992). Pedagogy of Hope. New York: The Continuum Publishing Group Company.

Freire, P. (1993). Pedagogy of the Oppressed. London: The Continuum International Publishing Group.

Frey, C. J., \& Whitehead, D. M. (2009). International education policies and the boundaries of global citizenship in the US. Journal of Curriculum Studies, 41(2), 269-290.

Gall, M. D., Gall, J. P., \& Borg, W. R. (2010). Educational Research: An Introduction ( $8^{\text {th }}$ ed.). New York: Allyn \& Bacon.

Gardiner, M. (2008). Education in rural areas: Issues in Education Policy. Retrieved from http://www.cepd.org.za/files/CEPD_Issues_in_education_Education_in_rural areas.pdf

Gelb, S. (2003). Inequality in South Africa: Nature, Causes and Responses. Retrieved from http://www.tips.org.za/files/Gelb Inequality in SouthAfrica.pdf.

Gonzalez-Perez, M. (2010). The civically engaged university model in Colombia. International Journal of Technology and Sustainable Development, 9(3), 161-173.

Grauer, K. (2012). A Case for Case Study Research in Education. In S. R. Klein (Ed.), Action Research Methods: Plain and simple. (pp. 69-79). New York, NY: Palgrave Macmillan.

Harding, J. (2013). Qualitative data analysis from start to finish. Los Angeles: SAGE.

Hart, A., Northmore, S., Gerhardt, C., \& Rodriguez, P. (2009). Developing Access between Universities and Local Community Groups: A University Helpdesk in Action. Journal of Higher Education Outreach and Engagement, 13(3), 45-59.

Hayden, M. (2013). A review of curriculum in the UK: internationalising in a changing context. The Curriculum Journal, 24(1), 8-26.

Hays, P. A. (2004). Case Study Research. In K. deMarrais, \& S. D. Lapan (Eds.). Foundations for Research: Methods of Inquiry in Education and the Social Sciences (pp. 217-234). New Jersey, NJ: Lawrence Erlbaum Associates. 
Henry, G. T. (2009). Practical sampling. In L. Bickman, \& D. J. Rog (Eds.), The SAGE Handbook of Applied Social Research Methods (2 ${ }^{\text {nd }}$ ed., pp.77-105). Thousand Oaks, CA: Sage.

Irwin, S. (2013). Qualitative secondary data analysis: Ethics, epistemology and context. Progress in Development Studies, 13(4), 295-306.

Jackson, D., Hutchinson, M., Peters, K., Luck, L., \& Saltman, D. (2013). Understanding avoidant leadership in health care: findings from a secondary analysis of two qualitative studies. 21, Journal of Nursing Management, 572-580.

Jenson, J., \& Saint-Martin, D. (2003). New Routes to Social Cohesion? Citizenship and the Social Investment State. Canadian Journal of Sociology, 28(1), 77-99.

Jones, M., \& Coffey, M. (2012). Voice hearing: A secondary analysis of talk by people who hear voices, International Journal of Mental Health Nursing, 21, 50-59.

Jorgenson, S., \& Shultz, L. (2012). Global Citizenship Education (GCE) in Post-Secondary Institutions: What is Protected and what is Hidden under the Umbrella of GCE? Journal of Global Citizenship, \& Equity Education, 2(1), 1-22.

Keating, A., Ortloff, D. H., \& Philippou, S. (2009). Introduction: Citizenship education curricula: the changes and challenges presented by global and European integration, 41(2), 145-158.

Kumar, R. (2011). Research Methodology: a step-by step guide for beginners ( $3^{\text {rd }}$ ed.). London: Sage Publications.

Lapum, J., Hamzavi, N., Veljkovic, K., Mohamed, Z., Pettinato, A., Silver, S., \& Taylor, E. (2012). A performance and poetical narrative of critical social theory in nursing education: an ending and threshold of social justice. Nursing Philosophy, 13, 27-45.

Lawrence, H. C., \& Gabriella, M. B. (2004). Experimental Research to Inform Educational Policy. In K. deMarrais, \& S. D. Lapan (Eds.), Foundations for Research: Methods of Inquiry in Education and the Social Sciences (pp. 329-352). New Jersey, NJ: Lawrence Erlbaum Associates.

Leibowitz, B. (2010). Towards SoTL as Critical Engagement: A Perspective from the “South". International Journal for the Scholarship of Teaching and Learning, 4(2), 1-5. 
Levine, P. (2007). The Future of Democracy: Developing the next generation of American Citizens. London: University Press of New England.

Lincoln, Y. S., Lynham, S. A., \& Guba, E. G. (2011). Paradigmatic controversies, contradictions, and emerging confluences, revisited. In N. K. Denzin, \& Y. S. Lincoln (Eds.), The SAGE Handbook of Qualitative Research (4 ${ }^{\text {th }}$ ed., pp. 97-128). Thousand Oaks, CA: Sage.

Lindenfeld, L. (2010). Working Outside the Box: Advertising Campaigns, Downtown Revitalization, and Community Engagement. Journal of Community Engagement, 1(2), $1-10$.

Lodico, M. G., Spaulding, D. T., \& Voegtle, K. H. (2010). Methods in Educational Research: From Theory to Practice ( $2^{\text {nd }}$ ed.). San Francisco: Jossey-Bass.

Loots, M. C. (2011). Teachers' implementation of an asset-based intervention for schoolbased psychosocial support, $\mathrm{PhD}$ thesis, University of Pretoria, Pretoria, viewed 27/06/2014 < http://upetd.up.ac.za/thesis/available/etd-06022011-161318/ >.

Machimana, E. G. (2012). Perceptions of the association between alcohol misuse and the risk of HIV-infection among male youths in Soshanguve, Gauteng province, MA dissertation, University of South Africa, Pretoria, viewed 2016/05/07.

Mahoney, J. L., Levine, M. D., \& Hinga, B. (2010). The Development of After-School Program Educators Through University-Community Partnerships. Applied Developmental Science, 14(2), 89-105.

Mampane, R., \& Bouwer, C. (2011). The influence of township schools on the resilience of their learners. South African Journal of Education, 31, 114-126.

Mapesela, M., Hlalele, D., \& Alexander, G. (2012). Overcoming Adversity: A Holistic Response to Creating Sustainable Rural Learning Ecologies. Journal of Human Ecology, 38(2), 91-103.

Maree, K., \& Pietersen, J. (2007). Sampling. In K. Maree, (Ed.), First Steps in Research (pp. 172-181). Pretoria, Van Schaik.

Mariage, T. V., \& Garmon, M. A. (2003). A Case of Educational Change: Improving Student Achievement Through a School-University Partnership. Remedial and special education, 24(4), 215-234. 
Markham, P. N. (2013). Bridging the Divide: From Service to Public Work. Journal of Community Engagement and Higher Education, 5(1), 68-73.

Mathee, A., Harpham, T., Barnes, B., Swart, A., Naidoo, S., De Wet, T., \& Becker, P. (2009). Inequality in poverty: the emerging public health challenge in Johannesburg. Development Southern Africa, 26(5), 722-732.

Maurrasse, D. J. (2001). Beyond the campus: How Colleges and Universities Form Partnerships with Their Communities. New York: Routledge.

May, J. (1998). Poverty and inequality in South Africa. Indicator South Africa, 53-58.

McLaren, P., \& Leonard, P. (1993). Paulo Freire: A critical encounter. London: Routledge.

McMillan, J., \& Schumacher, S. (2014). Research in Education: Evidence-based Inquiry ( $7^{\text {th }}$ ed.). Edinburg Gate: Pearson.

McNall, M., Reed, C. S., Brown, R., \& Allen, A. (2009). Brokering Community-University Engagement. Innovative Higher Education, 33, 317-331.

Mertens, D. M. (2004). Transformative Research and Evaluation and dimensions of diversity. In I. F. Shaw, J. C. Greene, \& M. M. Mark (Eds.), Handbook of Evaluation: Programme, Policy, and Practice: Proceedings of the Sixth International Conference on Logic and Methodology, Social Science Methodology in the New Mellennium held in Amsterdam, 17-20 August 2004 (pp.1-10). Retrieved from http://konference.fdvinfo. net/rc33/2004/ Data/PDF/stream 02-09.pdf

Mertens, D. M. (2005). The Transformative Prism: Resilience and Social Justice in Mixed Methods Research. Proceedings of the First International Congress of Qualitative Inquiry held in University of Illinois, Urban-Champaign, May 205 (pp. 1-10).

Mertens, D. M. (2012). Transformative Mixed methods: Addressing Inequalities. American Behavioral Scientist, 1-12.

Minkler, M. (2005). Community-Based Research Partnerships: Challenges and Opportunities. Journal of Urban Health, 82(2), 3-12.

Mitchell, M. L., \& Jolley, J. M. (2007). Research Design Explained (6 ${ }^{\text {th }}$ ed.). Australia: Thomson Wadsworth. 
Mooij, T., Smeets, E., \& De Wit, W. (2011). Multi-level aspects of social cohesion of secondary schools and pupils' feelings of safety. British Journal of Educational Psychology, 81, 369-390.

Morton, K., \& Enos, S. (n.d.). Building Deeper Civic Relationships and New and Improved Citizens. The Journal of Public Affairs, 83-102.

Moseley, W. G. (2007). Collaborating in the field, working for change: Reflecting on partnerships between academics, development organizations and rural communities in Africa. Singapore Journal of Tropical Geography, 28, 334-347.

Nattrass, N., \& Seekings, J. (2001). Democracy and distribution in highly unequal economies: the case of South Africa. Journal of Modern African Studies, 39(3), 471498.

Nestel, D., Gray, K., Simmons, M., Pritchard, S., Islam, R., ... Eng, A. (2014). Community perceptions of a rural medical school: a pilot qualitative study. Advances in Medical Education and Practice, 5, 407-413.

Neuman, W. L. (1997). Social Research Methods: Qualitative and Quantitative Approaches ( $3^{\text {rd }}$ ed.). London: Allyn and Bacon.

Osler, A. (2011). Teacher interpretations of citizenship education: national identity, cosmopolitan ideals, and political realities. Journal of Curriculum Studies, 43(1), 1-24.

Osman, R., \& Petersen, N. (2010). Students' Engagement with Engagement: The Case of Teacher Education Students in Higher Education in South Africa. British Journal of Educational Studies, 58(4), 407-419.

Oxfam. (2013). The cost of inequality: how wealth and income extremes hurt us all. Ref: 02/2013. Retrieved from http://www.oxfam.org/sites/www.oxfam.org/files/cost-ofinequality-oxfam-mb180113.pdf.

Pitso, P. (2014). Factors that promote or hinder the voice of the third sector in public service delivery: Perspective on the Batho Pele Principles. In R. Albertyn, \& M. Erasmus (Eds.), Knowledge as Enablement: Engagement between higher education and the third sector in South Africa (pp. 195-213). Bloemfontein: Sun Press.

Reitenauer, V. L., Spring, A., Kecskes, K., Kerrigan, S. M., Cress, C. M., \& Collier, P. J. (2005). Building a Maintaining Community Partnerships. In: Cress, CM, Collier, PJ, 
Reitenauer, VL, \& Associates. Learning through serving: A Student Guidebook for Service-Learning Across the Disciplines. Virginia: Stylus Publishing.

Robson, C. (2002). Real world research (2 $2^{\text {nd }}$ ed.). Malden: Blackwell Publishing.

Rohleder, P., Swartz, L., Carolissen, R., Bozalek, V., \& Leibowitz, B. (2008). “Communities Isn't Just About Trees and Shops": Students from Two South African Universities Engage in Dialogue About 'Community' and Community Work'. Journal of Community and Applied Social Psychology, 18, 253-267.

Seekings, J. (2007). The mutability of distributive justice attitudes in South Africa. South African Review of Sociology, 38, 1, 20-44.

Shields J., \& Bryan, E. (2012). Building a Policy-Oriented Research Partnership for Knowledge Mobilization and Knowledge Transfer: The Case of the Canadian Metropolis Project. Administrative Sciences, 2, 250-272.

Shultz, L. (2007). Educating for Global Citizenship: Conflicting Agendas and Understandings. The Alberta Journal of Education Research, 53(3), 248-258.

Slamat, J. (2010). Community Engagement as scholarship: a response to Hall. In Kagisano (ed.), Community Engagement in South African Higher Education (pp. 104-114). Pretoria: Jacana Media.

Statistics South Africa. (2014b). Poverty Trends in South Africa: An examination of absolute poverty between 2006 and 2011. Retrieved from http://www.ngopulse.org/resource/poverty-trends-south-africa-examination-absolutepoverty-between-2006-and-2011.

Strier, R. (2011). The construction of university-community partnerships: entangled perspectives. Higher Education, 62, 81-97.

The World Bank. (2012). South Africa Economic Update Focus on Inequality of Opportunity. Retrieved from http://siteresources.worldbank.org/INTAFRICA/Resources/257994-

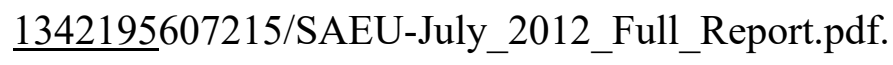

Tilbury, D. (2011). Education for Sustainable Development: An Expert Review of Process and Learning. Paris: UNESCO.

Trahair, J. F. (2013). Using the Vision of Community Engagement to Broaden the Tunnel Vision of Research Myopia. The International Journal of Science in Society, 4, 101109. 
Tregenna, F., \& Tsela, (2012). Inequality in South Africa: The distribution of income, expenditure and earnings. Development Southern Africa, 29(1), 35-61.

United Nations. (2013). Inequality Matters: Report of the World Social Situation 2013. Retrieved from http://www.un.org/esa/socdev/documents/reports/InequalityMatters.pdf.

Vargas, C. M., Arauza, C., Folsom, K., Luna, M. D., Gutiérrez, L., ... Frerking, P. O. (2012). A Community Engagement Process for Families with Children with Disabilities: Lessons in Leadership and Policy. Maternal Child Health Journal, 16, 21-30.

Venter, M. (2013). A teachers' experience of implementing the asset-based approach to teach Grade 7 learners, MEd dissertation, University of Pretoria, Pretoria, viewed 2016/06/04 http://hdl.handle.net/2263/40451.

Wagner, C. S., \& Alexander, J. (2013). Evaluating transformative research programmes: A case study of the NSF Small Grants for Exploratory Research programme. Research Evaluation, 22, 187-197.

Webber, R., \& Jones, K. (2011). Re-positioning as a response to government higher education policy development- an Australian case study. Journal of Higher Education Policy and Management, 33(1), 17-26.

Welman, C., Kruger, F., \& Mitchell, B. 2005. Research methodology ( ${ }^{\text {rd }}$ ed.). Cape Town: Oxford University Press Southern Africa.

Whitehead, K. A., Kriel, A. J., \& Richter, L. M. (2005). Barriers to conducting a community mobilization intervention among youth in a rural South African Community. Journal of Community Psychology, 33(3), 253-259. 